\title{
Benign Connective and Soft Tissue Neoplasm
}

National Cancer Institute

\section{Source}

National Cancer Institute. Benign Connective and Soft Tissue Neoplasm. NCI Thesaurus.

Code C53684.

A non-metastasizing neoplasm that arises from the connective and soft tissue.

Representative examples include lipoma, leiomyoma, fibroma, and osteoma. 